\title{
Kan man avgöra om en text är översatt eller inte? Några synpunkter på översättningskritikens praktik
}

\author{
Av Mathias Pålsson, doktorand i franska
}

\author{
Länk till presentation av Mathias Pålsson
}

\begin{abstract}
Vi har väl alla vid ett eller annat tillfälle beklagat oss över kvaliteten på den ena eller den andra översättningen. Det kan vara framför TV:n där vi konstaterar hur otroligt inkompetent en viss översättare tycks vara då vi märker hur ord efter ord lämnas oöversatt eller än värre felöversätts. Och hur många av oss har inte under läsningen av en roman tagit oss för pannan och utropat: — Så där säger man väl ändå inte på svenska!
\end{abstract}

Synpunkter på översättningars kvalitet förekommer även i bokrecensioner, och det är då inte sällan i ganska svepande och kategoriska ordalag som t ex "språkdräkten känns inte riktigt svensk", språket flyter inte" eller "den engelska originaltexten lyser igenom" etc. Naturligtvis förekommer även beröm och det talas om "översättningsbragd" eller "kongenial överföring till svenska". Ibland finner recensenten det för gott att citera en fras eller en kort passage för att underbygga sina påståenden om översättningens kvalitet. Denna typ av översättningskritik, om man nu bör kalla den översättningskritik, bygger bl a på antagandet att recensenten vet vad som kännetecknar en bra översättning. Att påstå att något inte "låter" riktigt svenskt förutsätter dessutom kunskap om hur svensk text ser ut. Och att veta hur en svensk text ser ut är viktigt, eftersom det knappast utan denna kunskap är möjligt att skilja texter som ursprungligen är skrivna på svenska från texter som är översatta till svenska.

Men hur pass välgrundat är, eller rättare sagt, kan ett sådant antagande vara? Är det verkligen möjligt att avgöra om en text är översatt eller inte? Och på vilka grunder kan man i så fall göra det? Eftersom min avhandling handlar om översättning av svensk skönlitteratur till franska, i synnerhet det lilla ordet $n u$, är dessa frågeställningar inte vare sig okända eller ovidkommande, och även om de kanske inte utgör de mest centrala i avhandlingsarbetet, är de ändå av principiellt intresse. Jag vill därför lägga fram några av mina funderingar till diskussion; för att kunna säga något om möjligheten att avgöra om en text är översatt eller inte kommer dessa funderingar att kretsa kring följande tre frågor:

1. Vad är en översättning?

2. Hur går det till att översätta?

3. Kan man avgöra om en text är översatt?

\section{Vad är en översättning?}

Om man vill ge en enkel men brukbar definition av översättning kan man säga att översättning är överföring av ett skriftligt budskap från ett språk till ett annat. (När det gäller överföring av ett muntligt budskap använder man hellre termen tolkning.) För att på ett praktiskt sätt kunna beskriva de olika delarna i denna överföring talar man vanligen om källspråk, som betecknar utgångsspråket från vilket översättning äger rum, och om målspråk, som är det språk till vilket översättning sker. Eftersom källspråk och målspråk så gott som alltid skiljer sig åt såväl syntaktiskt som lexikaliskt räcker det sällan att helt mekaniskt byta ut ord eller fraser för att få en bra översättning. Det säger t ex sig självt att tyskans "dass sie den Wagen gekauft hat" inte gärna kan översättas till svenska med "att hon bilen köpt har" o s v. Det blir därför ibland nödvändigt att prioritera innehållet framför formen, bl a beroende på de kulturella skillnader som kan finnas i uttryckssättet mellan källspråk och målspråk. Den fråga som är relevant här gäller om det är skillnad på sådan 
text som är skriven på svenska (originaltext) och sådan text som är översatt från ett annat språk, t ex franska, men de facto är skriven på svenska (måltext). Finns det så att säga spår kvar från källtexten i den nya måltexten? Och om sådana finns, kan de identifieras?

\section{Hur går det till att översätta?}

Man kan säga att översättning normalt föregår i tre moment:

1. källtextsanalys

2. överföring av källtext till måltext

3. bearbetning av måltext

Denna beskrivning av översättningsprocessen är inte oemotsagd, men verkar ändå kunna accepteras av flertalet översättningsforskare och översättare, varför jag kommer att utgå från denna uppfattning. Vad gäller det första momentet, källtextanalysen påpekar t ex Lundquist (1994 s 19-20) att denna ställer flera krav på översättaren som bl a måste förstå:

- det emne teksten handler om

- emnets tilhørsforhold i en større emneskreds eller område

- det er i det emnesområde man skal hente ordforrådet

- forfatternes holdning til emnet: er han objektiv/neutral eller er han subjektiv? Og hvis subjektiv, er han så negativ eller positiv?

- tekstens orientering mod en bestemt slutning, dens "argumentative retning"

- forfattarens intention med teksten (tekstens formål)

- væsentlige stiltræk og stilniveau (der findes forskellige niveauer i stilistikker for forskellige sprog)

- tekstens grad af variation

- sammenhængen mellem sættningerne

Dessa punkter, som känns igen från tysk översättningsteori (t ex Reiss 1971), är viktiga mementon inte bara för en översättare utan också för en bokrecensent som kommenterar en viss översättnings kvalitet. För översättaren är det fråga om att utföra en tämligen noggrann textanalys innan själva överföringen från källtext till måltext påbörjas; på bokrecensenten är kraven till och med något högre beroende på vad han avser bedöma. Är det måltextens trogenhet i förhållande till källtexten som bedöms, måste såväl källtext som måltext analyseras. Är det måltextens kvalitet i förhållande till andra måltexter (och originaltexter), står han inför den typ av problem som diskuteras i denna artikel. Vilka krav som kan ställas på kommentarer från TV-soffan lämnar jag åt envar att bedöma efter eget samvete.

Det bör understrykas att den beskrivning som presenteras här inte redogör för hur översättning i praktiken går till utan bara anger en modell för hur det under ideala förhållanden skulle kunna ske. Som t ex Liungman (1991) påpekar läser vissa översättare inte alltid källtexten i dess helhet innan överföringsmomentet påbörjas. Detta kan enligt Liungman förklaras med den tidspress som kännetecknar en hel del

översättningsverksamhet: det finns helt enkelt inte alltid tid att först läsa texten i sin helhet och därefter underkasta den en noggrann analys. Under sådana omständigheter får översättaren väsentligen lita på sin erfarenhet och förmåga att intuitivt finna rätt "tonfall". När det gäller förmågan att hitta rätt tonfall, kan det vara på sin plats att uppmärksamma en nyutkommen svensk studie inom den mycket intressanta gren av översättningsvetenskapen som undersöker översättarstrategier, nämligen Christina Gullins doktorsavhandling Översättarens röst (1997).

Det andra momentet är överföring från källtext till måltext. Det finns här flera olika strategier att ty sig till. Rune Ingo (1991) ger en kortfattad översikt över de vanligast förekommande översättningsstrategierna, medan Arnt Lykke Jacobsen (1994) är något utförligare. Lita Lundquist (1994) presenterar följande uppsättning av par:

ordret oversættelse åben oversættelse trofast oversættelse formel oversættelse fri oversættelse dækket oversættelse 'troløs' oversættelse funktionel oversættelse 
Dessa dikotomier kan vid en grov generalisering sägas gå tillbaka på den tyske filosofen och teologen Friedrich Schleiermachers (1768-1834) uppfattning om att översättaren antingen kan låta läsaren närma sig (käll)texten eller låta (käll)texten närma sig läsaren. Detta innebär i det första fallet att översättaren inte fullständigt anpassar måltexten till andra texter skrivna på målspråket. Om läsaren således inte känner till källspråkskulturen, så förstår han eller hon inte heller vad som avses. Ett exempel på detta är översättningen av titeln på François Truffauts debutfilm Les quatre cents coups, som på svenska blivit De 400 slagen. I det andra fallet gäller att översättaren anpassar och bearbetar texten på ett sådant sätt att även den läsare som inte överhuvudtaget känner till källspråkskulturen kan förstå. Om man tillämpade denna andra strategi på Les quatre cents coups skulle man troligen få en översättning som hade med bus och busliv att göra, eftersom uttrycket faire les quatre cents coups på franska betyder att hitta på bus och göra rackartyg.

Vad det handlar om här är alltså den grad av ekvivalens som kännetecknar en översättning. Å ena sidan kan ekvivalensen vara formell, d v s ofta på ett syntaktiskt och lexikaliskt plan. Å andra sidan kan den vara dynamisk, d v s ofta likvärdig inte till formen, men väl till innehållet. Den som är intresserad av konkret belysning av dessa frågeställningar kan med förväntad behållning läsa Inger Enkvists intressanta Om litterär översättning från spanska (1991) som tar upp översättningar till engelska, franska och svenska av den peruanske författaren Mario Vargas Llosas romaner. Den fråga som ägnas störst utrymme i framställningen gäller vilka svårigheter som möter den läsare som tar i tu med en latinamerikansk roman: är det latinamerikanska ord som kan finnas kvar i målspråket, är det den främmande miljön, är det berättartekniken o s v?

Det tredje momentet består i bearbetning av måltexten. Detta är det sista momentet $\mathrm{i}$ översättningsprocessen och ställer naturligtvis krav på att den färdiga produkten kan stå på egna ben. Det innebär att den ska vara helt anpassad till målspråkets konventioner vad beträffar stavning, skiljetecken och meningsbyggnad. Men vad betyder då detta? Jo, inte nog med att översättaren måste respektera de rent grammatiska konventioner som råder i målspråket, hon måste också, som Lundquist inskärper, respektera källtextens logiska, semantiska och argumentativa sammanhang och intention. Det är naturligtvis mycket svårt att tillmötesgå samtliga dessa krav och synnerligen svårt är det att respektera målspråkets alla konventioner, eftersom det inte är helt lätt att veta vilka de är. Vi är med andra ord framme vid huvudfrågan: kan man avgöra om en text är översatt eller inte?

\section{Kan man avgöra om en text är översatt?}

Det enklaste och tillförlitligaste sättet att få reda på om en text är översatt eller inte är förstås att gå till bokens försättssidor och där leta efter upplysningar om originaltitel och översättare. Men om man undantar denna möjlighet, vilket är högst ändamålsenligt med tanke på denna artikels existensberättigande, vad står då till buds? Ja, att säga hur en svensk text ser ut är som sagt inte alldeles givet. Martin Gellerstam $(1986,1996)$ har mycket förtjänstfullt jämfört svenska originaltexter med svenska måltexter översatta från engelska, och resultatet stämmer till eftertanke. Till exempel förekommer de svenska formerna 'mej', 'säja' och 'nån' ofta i svenska originaltexter (OT), men mycket sällan i svenska måltexter (MT). För dessa tre former har jag från Gellerstam hämtat följande siffror:

$\begin{array}{llll}\text { Ordform } & & \text { OT } & \text { MT } \\ \text { 'mej' } & & 3795 & 20 \\ \text { 'säja' } & & 360 & 2 \\ \text { 'nån' } & & 3112 & 0\end{array}$

OT-kolumnen anger förekomsten av ordformerna 'mej', 'säja' och 'nån' i svenska originaltexter medan MT-kolumnen redovisar förekomsten i motsvarande textmängd svenska måltexter. (För närmare uppgifter om metod och korpus, se Gellerstam 1986 och 
1996.) Gellerstams fakta måste nu problematiseras. Om, vilket vi tidigare sagt, översättningar (måltexterna) ska vara helt anpassade till målspråkets konventioner vad beträffar stavning, skiljetecken och meningsbyggnad, så står vi inför ett visst huvudbry, eftersom måltexterna inte verkar följa originaltexterna på denna punkt, åtminstone inte på det lexikala planet. Att utan vidare hävda att originaltext ska vara normerande förefaller inte självklart. Vi ser nämligen att svenska författare tycks föredra 'mej', 'säja' och 'nån' där översättarna väljer 'mig', 'säga' och 'någon'. Ett delikat problem blir nu att veta eller försöka avgöra vilka texter som är mest "typiska" för just svenska texter. Är det svenska originaltexter eller svenska måltexter?

Man kan kvalitativt tycka att svenska originaltexter måste anses som mest representativa, eftersom ju dessa återspeglar ett språkbruk som föredragits av våra främsta svenska författare. Även om svenska författare inte har lika stor pondus som t ex franska författare har i språknormerande frågor, är det mycket som talar för att låta deras texter (OT) utgöra urtypen för svensk skönlitterär text. Men då får man ju å andra sidan också acceptera formerna 'mej', 'säja' och 'nån', vilket inte alla kanske är beredda att göra, åtminstone inte i skrift. Om inte detta kvalitativa argument förmår avgöra saken kan man fråga sig vilka andra bevekelsegrunder som står till förfogande. Är det rimligt att i stället låta kvantitativa hänsyn ligga till grund för måltextens utformning? Utgångspunkten för ett sådant resonemang är nämligen att antalet utgivna svenska måltexter, räknat i skönlitterära titlar per år, vida överträffar antalet utgivna svenska originaltexter. Att på grundval av kvantitativa förhållanden påstå att svensk måltext är mest representativ låter sig göras, och då finner man att formerna 'mig', 'säga' och 'någon' så gott som undantagslöst förekommer.

På frågan om man kan avgöra huruvida en text är översatt eller inte, verkar vi emellertid kunna redovisa ett preliminärt svar: om de vedertagna skriftformerna 'mig', 'säga' och 'någon' förekommer, kan detta rimligtvis tolkas som ett indicium på att det rör sig om måltext. Är det emellertid så att formerna 'mej', 'säja' och 'nån' figurerar, finns det anledning att sluta sig till att det handlar om originaltext.

Är detta riktigt klokt? Ja, man kan konstatera att måltexter på vissa punkter - vi talar ju här endast om ett begränsat fenomen på lexikal nivå - förefaller stämma mer överens med vår uppfattning om hur svensk skönlitterär text bör skrivas än hur svensk skönlitteratur faktiskt skrivs av våra svenska författare. Hur ska detta förklaras? Det ligger nära till hands att påstå att svenska måltexter genomgår ett slags hyperkorrektion: översättningsfel är till den grad stigmatiserade att svenska måltexter måste vara formulerade på så oklanderlig svenska att produkten i viss mån fjärmar sig från den svenska som skrivs av svenska författare. Detta ligger väl i linje med det faktum att en författare kan, för att inte säga bör, ta sig vissa friheter och kanske hålla en viss skeptisk distans till språkriktighet. Naturligtvis gäller detta även översättare, men där finns en liten skillnad, och denna lilla skillnad har att göra med den syn på översättning som vissa bokrecensenter verkar ha och som kanske kan förklaras i termer av översättarstrategi. Å ena sidan kan man utgå från att en bra måltext kännetecknas av hur formellt trogen den är källtexten. Å andra sidan kan man utgå från att en bra måltext kännetecknas av hur pass väl den fungerar i förhållande till andra texter på målspråket. De anmärkningar som lämnas på översättningar i t ex bokrecensioner kan inte sällan hänföras till den andra kategorin och avser således hur väl texten fungerar bland andra texter på målspråket. Eftersom denna bedömning så gott som undantagslöst förefaller grunda sig på recensentens språkkänsla, finns det enligt min mening anledning att förhålla sig sunt skeptisk till validiteten hos denna typ av kritik[1]. Ibland är det emellertid den formella trogenheten som kommenteras och recensenten återger då ofta en fras eller en kort passage för att belägga sina påståenden om översättningens kvalitet. Översättare är naturligtvis medvetna om att deras måltext riskerar att enbart bedömas med avseende på just formell trogenhet och formalia. Och för att minimera den risk som det innebär för översättaren att avvika från t ex skriftspråksnormen på lexikal nivå, vilket är det som vi uppmärksammat här, kan resultatet bli ett slags överdriven språkriktighet som — paradoxalt nog — i sin tur avviker från de texter (OT) som skrivs direkt på målspråket. Översättarnas strategi är emellertid helt förståelig med tanke på att översättandet ofta är ett levebröd som i hög grad kan påverkas av en dålig recension. 
En möjlig förklaring till att måltexter i vissa sammanhang tenderar att bedömas utifrån formell trogenhet mot källtexten, och inte utifrån anpassning till originaltexter, kan vara de förutfattade meningar som finns i synen på författande och översättande: i det förra fallet är det fråga om konstverk, vilket inbjuder till så gott som obegränsad frihet, i det andra fallet gäller det snarare ett hantverk, vilket ger avsevärt mindre spelrum för avvikelser. Översättarens verksamhet reduceras enligt denna syn till en snävt mekanisk syssla där självständighet helst inte ska ingå. Men distinktionen hantverk/konstverk är i realiteten inte särskilt intressant eftersom det är helt självklart att varken författande eller översättande vore möjligt utan inslag av bådadera.

Vad kan man då dra för slutsats? Som framgått av resonemanget är det knappast meningsfullt att påstå saker om en måltext utan att ha gjort en noggrann analys. Det räcker alltså inte att peka på ett eller annat felöversatt ord eller på ett eller annat missförstånd. I denna fråga intar vissa bokrecensenters intuitiva och ofta oproblematiserade omdömen en tvivelaktig position. Måltexter måste i likhet med källtexter underkastas en textanalys där eventuella påståenden om texten styrks på så många olika nivåer som möjligt.

Då det gäller att avgöra om en text är översatt eller inte kan man alltid ställa sig två frågor: när har översättaren följt källspråkets struktur och när har han avvikit från denna? Om översättaren följt källspråkets struktur, kan man ta ställning till om översättaren gjort detta alltför osjälvständigt; måltexten uppvisar då källspråklig interferens. I det andra fallet, när översättaren avvikit från källtexten, måste man fråga sig om dessa avvikelser varit föranledda av språkstrukturella skillnader (d v s varit nödvändiga för att få acceptabel måltext) eller om de betingats av andra skäl (d v s inte varit nödvändiga för att få acceptabel måltext)[2]. Ingo (1991: 240-59) menar t ex att översättarens avvikelser måste betecknas som antingen obligatoriska eller frivilliga. En grannlaga uppgift blir då att avgöra vad som är frivilligt och vad som är obligatoriskt. Om man till exempel påstår att 'gå vägen fram' är en nödvändig översättning av engelskans 'walk along the road' eftersom 'gå längs vägen' betyder något annat på svenska, bör detta påstående enligt min mening styrkas med material från svensk originaltext. Visar det sig att uttrycket 'gå längs vägen' är vanligt i svenska originaltexter, kan man knappast med anspråk på trovärdighet hävda att 'gå vägen fram' är en nödvändig översättning.

Det torde av ovanstående ha framgått att det finns betydande svårigheter i att på språklig grund kunna avgöra om en given text är översatt eller inte. Den problematik som kortfattat diskuterats inom ramen för denna uppsats ger vid handen att det är svårt att peka ut och isolera språkliga element till stöd för en viss ståndpunkt. Det är sant att vissa former och vändningar kan antas vara indicier på måltext: ett sådant indicium skulle märkligt nog kunna vara ett hyperkorrigerat språkbruk, präglat av fullständig anpassning till den skriftspråkliga normen.

(C) Mathias Pålsson

\section{Litteratur}

\section{GELLERSTAM, M.}

- 1986, "Translationese in Swedish novels translated from English », i WOLLIN, L. \& LINDQVIST, H. (red.), 1986, Translation Studies in Scandinavia, Lund: Lund University Press.

— 1996, « Anföringens estetik », i JOSEPHSON, O. (red), 1996, Stilstudier, Uppsala: Hallgren \& Fallgren.

ENKVIST, I., 1991, Om litterär översättning från spanska, Surte: Almqvist \& Wiksell International.

GULLIN, C., 1998, Översättarens röst : en studie i den skönlitteräre översättarens roll med utgångspunkt i översättningar av Else Lundgren och Caj Lundgren, Lund: Lund University Press INGO, R., 1991, Från källspråk till målspråk. Introduktion i översättningsvetenskap, Lund : Studentlitteratur. 
JACOBSEN, A. L. (red.), 1994, Translating LSP texts: Some theoretical Considerations, Copenhagen Studies in Language 16, Köpenhamn: Samfundslitteratur.

LIUNGMAN., C.-G., 1991, Att översätta böcker, Malmö: Polaris.

LUNDQUIST, L., 1994, Oversettelse. Problemer og strategier, set i tekstlingvistisk og pragmatisk perspektiv, Fredriksberg C: Samfundslitteratur.

PLATZACK, C.,1983, « Sex översättningar till svenska av Lewis Carrolls Alice in Wonderland » i ENGWALL, G \& af GEIJERSTAM, R. (red.), 1983, Från språk till språk, Lund: Studentlitteratur.

REISS, K., 1971, Möglichkeiten und Grenzen der Übersetzungskritik, München.

[1] En recension med många förtjänster i detta avseende och som avviker från strömfåran är den understreckare (Svenska Dagbladet 1993-10-22) som översättaren Jan Stolpe ägnar åt den svenska översättningen av Stendhals roman Armance (1827) utgiven på bokförlaget Symposion 1992. I artikeln som bär rubriken "Lektion i översättandet svåra konst" leder Stolpe, efter att ha redovisat åtskilliga instruktiva exempel, läsaren fram till slutsatsen att originalspråkets struktur måste smältas ner och en ny byggas upp för att undvika en osäker, oprecis och gungig svensk text.

[2] En intressant studie när det gäller att belysa de allmänna problem som en översättare ställs inför är Christer Platzacks "Sex översättningar till svenska av Lewis Carrolls Alice in Wonderland". 